\title{
Resistance Determinants of Pseudomonas Species from Aquaculture in Australia
}

\author{
Olasumbo L Ndi* and Mary D Barton
}

Sansom Institute, School of Pharmaceutical and Medical Sciences, University of South Australia, G.P.O Box 2471, Adelaide SA 5001

\begin{abstract}
There is limited information on antibiotic resistance determinants present in bacteria of aquaculture origin in Australia. The presence of integron and other resistance determinants was investigated in 129 Pseudomonas isolates derived from nine freshwater trout farms in Victoria (Australia). Polymerase chain reaction (PCR) was carried out for the detection of integrase genes Int1, Int2 and Int3, gene cassette array, integron-associated aadA, beta-lactamase resistance genes blaTEM and blaSHV. Genes coding for efflux pump mexA, mexB and oprM were also investigated as well as cadA and czr which are known to mediate resistance to cadmium.
\end{abstract}

Class 1 integrons were detected in 30/129 (23\%) isolates while class 2 and class 3 was not detected in any of the isolates. aadA gene was detected in 28 of the 59 integrase positive isolates which are also resistant to streptomycin. The strA-strB, blaTEM or blaSHV genes were not detected in any of the strains. mexB was detected in $85 / 129$ isolates and cadA gene in 59/92 isolates tested.

The sequence analysis mexB from this study demonstrated similarity to the RND multidrug efflux transporter mexB and its homologue TtgB which in addition to multidrug efflux also transports toluene out of the cell. The sequence analysis of cadA confirms similarities to the cadmium translocating P-type ATPases, cadA of various Pseudomonas spp.

Pseudomonas spp. carrying integrons, efflux gene and cadmium resistance genes are present in farm-raised fish and sediments even though no antibiotics were licensed for use in Australian aquaculture at the time of the study.

Keywords: Antibiotic resistance; Heavy metal resistance; Aquaculture; Pseudomonas species; Australia

\section{Introduction}

Members of the genus Pseudomonas are a ubiquitous group of Gram-negative, motile, rod-shaped bacteria known for their metabolic versatility with genetic and physiologic capabilities that allow them to flourish in environments hostile to many other bacteria. It is one of the most diverse bacterial genera, containing over 60 validly described species [1]. Some species of Pseudomonad particularly $P$. aeruginosa are opportunistic pathogens that can cause serious and life-threatening infections in immunocompromised and cystic fibrosis patients [2,3]. In aquaculture, $P$. aeruginos $a$ and $P$. fluorescens especially are the most frequently isolated opportunistic pathogenic species [4,5] although other species may also be serious opportunistic pathogens, including P. anguilliseptica in eels, Anguilla japonica [6] P. chlororaphis in amago trout, Oncorhynchus rhodurus [7], P. plecoglossicida in ayu, P. altivelis [8] and more recently $P$. putida in rainbow trout, Oncorhynchus mykiss [9].

Pseudomonas spp. express natural resistance to many antibiotics, heavy metals and biocides and this resistance is usually higher in $P$. aeruginosa than in other Pseudomonads [10,11]. Pseudomonas spp. have the capacity to acquire many additional mechanisms of resistance for antibiotics and heavy metals by integrons and (or) plasmids [12-14], as well as multidrug active efflux [15-20].

The objective of this study was to identify integrons and genes coding for multidrug efflux pumps such as mexAB-oprM which is known to contribute greatly to the natural resistance seen in Pseudomonas spp. These pumps have broad substrate specificity and may act synergistically with the permeability barrier to result in significant intrinsic resistance to many antimicrobials including $\beta$-lactams, $\beta$-lactamase inhibitors, quinolones, chloramphenicol, tetracycline, trimethoprim, sulphamethoxazole and novobiocin [21,22]. Although 12 potential efflux systems of this family have been identified in the P. aeruginosa genome [23], four of them are best characterised as antibiotic transporters [24]. This study also determined the mechanisms of intrinsic antibiotic resistance and resistance to cadmium, one of the heavy metals tested. Several mechanisms have been identified within bacteria that confer cadmium resistance. These include sequestration by metallothionein-like proteins and ATPase (cad operon) and nonATPase (czc operon) efflux pumps. Metallothionein-like proteins that sequester cadmium have been identified in the Cyanobacterium Synechococcus and $P$. putida, whereas the czc resistance operon has been found in Alcaligenes spp [25,26] and P. aeruginosa [27].

\section{Materials and Methods}

\section{Bacterial strains and plasmids}

One hundred and twenty nine Pseudomonas spp. isolated from healthy fish and sediments from nine freshwater trout farms in Victoria (Australia) between August and December 2004 were used in this study. Isolation, identification, heavy metal and antibiotic sensitivity

*Corresponding author: Olasumbo L Ndi, Sansom Institute, School of Pharmacy and Medical Sciences, University of South Australia, G.P.O Box 2471, Adelaide SA 5001, Tel: +61 88302 2933; Fax: +61 88302 2389; E-mail: Sumbo.Ndi@unisa.edu.au

Received November 14, 2011; Accepted December 22, 2011; Published December 30, 2011

Citation: Ndi OL, Barton MD (2012) Resistance Determinants of Pseudomonas Species from Aquaculture in Australia. J Aquac Res Development 3:119 doi:10.4172/2155-9546.1000119

Copyright: @ 2012 Ndi OL, et al. This is an open-access article distributed under the terms of the Creative Commons Attribution License, which permits unrestricted use, distribution, and reproduction in any medium, provided the original author and source are credited. 
Citation: Ndi OL, Barton MD (2012) Resistance Determinants of Pseudomonas Species from Aquaculture in Australia. J Aquac Res Development 3:119 doi:10.4172/2155-9546.1000119

Page 2 of 6

testing have been previously described [28]. The positive controls used were Escherichia coli strains containing integron plasmids; pR388, a class 1 integron with a two cassette array dfrB2 and orfA and pR1033 that contains Tn1496 which in turn contains a class 1 integron with four cassettes, aac, orfE, aadA2 and cmlA, (kindly provided by Hatch Stokes, Macquarie University, Sydney, Australia) and an E. coli strain with the Int2 gene. Escherichia coli strain JIR5431 (Burdett 1996) carrying a tetM gene (kindly provided by Julian Rood, Monash University, Melbourne, Australia) and Aeromonas strains WA13 (tetA), WA14 (tetD) and WA18 (tetE) were from the culture collection of our laboratory (University of south Australia).

\section{Total and plasmid DNA extraction}

DNA was extracted by inoculating isolates into Tryptone Soy Broth (Oxoid CM0129) and incubating overnight at $30^{\circ} \mathrm{C}$. A $1.5-\mathrm{ml}$ amount was dispensed into Eppendorf tubes and centrifuged at $12662 \mathrm{~g}$ for 5 min. The supernatant was discarded and cell pellets re-suspended in $200 \mu \mathrm{l} \mathrm{TE}$ buffer, and they were then heated in the heating block at $95^{\circ} \mathrm{C}$ for $10 \mathrm{~min}$. The samples were placed on ice to cool and then centrifuged at $12662 \mathrm{~g}$ for $5 \mathrm{~min}$, and the supernatants were transferred into fresh Eppendorf tubes and these served as DNA templates for polymerase chain reaction (PCR). For plasmid DNA extraction, cell pellets were extracted by alkaline lysis of cells [32].

\section{PCR amplification of 16 S rRNA}

16S rRNA gene universal primers were used for the PCR amplification of the Pseudomonas spp. to confirm the identification obtained by the biochemical method. The primers used for PCR are listed in Table 1. The reaction mixture (final volume $25 \mu \mathrm{L}$ ) contained $10 \times$ PCR buffer $\left(1.5 \mathrm{~mm} \mathrm{MgCl}, 10 \mathrm{~mm}\right.$ Tris- $\mathrm{HCl}\left(\mathrm{pH} 8.8\right.$ at $\left.25^{\circ} \mathrm{C}\right)$, $50 \mathrm{~mm} \mathrm{KCl}$ and $0.1 \%$ Triton X-100), $200 \mu \mathrm{m}$ of each deoxynucleotide triphosphate, $0.5 \mu \mathrm{m} \mathrm{L}^{-1}$ of each oligonucleotide primer and $0.25 \mu \mathrm{L}$

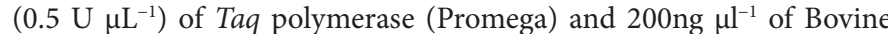
serum albumin. A $5 \mu \mathrm{L}$ volume of DNA template was added to each reaction tube. The cycling conditions were as follows: $95^{\circ} \mathrm{C}$ for $5 \mathrm{~min}$, 30 cycles of denaturation $94^{\circ} \mathrm{C}$ for $30 \mathrm{~s}$, annealing at $68^{\circ} \mathrm{C}$ for $60 \mathrm{~s}$ and extension at $72^{\circ} \mathrm{C}$ for $60 \mathrm{~s}$ and a final single cycle of extension at $72^{\circ} \mathrm{C}$ for $10 \mathrm{~min}$.

The PCR products were analysed by electrophoresis on $1.5 \%$ agarose gels, stained with ethidium bromide and visualised using the Biorad Gel Documentation system (GelDoc).

\section{Integron PCR}

Detection of integrons and the resistant gene cassette was performed using PCR amplification with the specific primers listed in Table 1. All PCR amplification was carried out in a BioRad MyCycler thermal cycler. Integrase genes Int 1 , Int 2 and Int 3 were targeted in a multiplex PCR as previously described [29] using primers Int1F-Int1R [30], Int2F-Int2R and Int3F-Int3R [31]. Assays were carried out in $25 \mu \mathrm{L}$ volumes containing $2.5 \mu \mathrm{L}$ of $10 \times$ PCR buffer [ $100 \mathrm{mM}$ Tris- $\mathrm{HCl}(\mathrm{pH}$ 8.8), $500 \mathrm{mM} \mathrm{KCl}, 15 \mathrm{mM} \mathrm{MgCl}_{2}$ and $1 \%$ Triton X-100], $0.5 \mu \mathrm{L}$ of 10 mM DNTP, $1 \mu \mathrm{L}$ of each primer stock solution $\left.\left(25 \mathrm{pmol} \mu \mathrm{L}^{-1}\right)\right]$ and 0.25 $\mu \mathrm{L}$ of BioTaq polymerase $\left(5 \mathrm{U}^{-1} \mathrm{~L}^{-1}\right)$. Three microlitres of the prepared DNA extract was added to provide the DNA template. A volume of $16.75 \mu \mathrm{L}$ sterile milliQ water was added to make up the volume to 25 $\mu \mathrm{L}$. All PCRs were subjected to an initial denaturation step at $94^{\circ} \mathrm{C}$ for 5

\begin{tabular}{|c|c|c|c|c|}
\hline Gene & Primer sequence & Product size (bp) & Accession number & Reference \\
\hline $\begin{array}{l}\text { Uni (16S rDNA) (F) } \\
\text { Uni (16S rDNA) (R) }\end{array}$ & $\begin{array}{l}\text { TGC CAG CAG CCG CGG TA } \\
\text { GAC GGG CGG TGT GTA CAA }\end{array}$ & 990 & & {$[60]$} \\
\hline $\begin{array}{l}\text { Int1- } F^{*} \\
\text { Int1-R }\end{array}$ & $\begin{array}{l}\text { CAG TGG ACA TAA GCC TGT TC } \\
\text { CCC GAG GCA TAG ACT GTA }\end{array}$ & 160 & & [30] \\
\hline $\begin{array}{l}\text { Int2-F } \\
\text { Int2-R }\end{array}$ & $\begin{array}{l}\text { GTA GCAAAC GAG TGA CGAAAT G } \\
\text { CAC GGA TAT GCG ACAAAAAGG T }\end{array}$ & 788 & & {$[31]$} \\
\hline $\begin{array}{l}\text { Int3-F } \\
\text { Int3-R }\end{array}$ & $\begin{array}{l}\text { GCC TCC GGC AGC GAC TTT CAG } \\
\text { ACG GAT CTG CCAAAC CTG ACT }\end{array}$ & 979 & & {$[31]$} \\
\hline $\begin{array}{l}\text { bla }_{\text {TEM }}-\mathrm{F} \\
\text { bla }_{\text {TEM }}-R\end{array}$ & $\begin{array}{l}\text { ATG AGT ATT CAA CAT TTC CG } \\
\text { CTG ACA GTTACC AATGCT TA }\end{array}$ & 867 & & [61] \\
\hline $\begin{array}{l}\text { bla }_{\mathrm{SHV}}-\mathrm{F} \\
\text { bla }_{\mathrm{SHV}}-\mathrm{R}\end{array}$ & $\begin{array}{l}\text { GGT TATGCG TTA TAT TCG CC } \\
\text { TTAGCT TTGCCAGTGCTC }\end{array}$ & 867 & & [61] \\
\hline $\begin{array}{l}\text { mexAB-oprM-F } \\
\text { mexAB-oprM-R }\end{array}$ & $\begin{array}{l}\text { CTC ATG AGG ACA ACG CTA TGC AAC GAA CG } \\
\text { TGG GTC AGG TCG AAA CTC TTC TGG TAGGTG }\end{array}$ & $4.9 \mathrm{~kb}$ & $a$ & [62] \\
\hline $\operatorname{mexA-F}$ & $\begin{array}{l}\text { ATC CTC AAG CGC CTG TTC AAG GAA } \\
\text { ACT GCA GGC CTT CGG TAA TGA TCT }\end{array}$ & 832 & $a$ & This study \\
\hline $\begin{array}{l}\operatorname{mexB}-\mathrm{F} \\
\operatorname{mexB}-\mathrm{F}\end{array}$ & $\begin{array}{l}\text { ACT TCT TCA GCT TCA AGG ACG CGA } \\
\text { ACG GAA TCG ACC AGC TTT CGT ACA }\end{array}$ & 732 & $a$ & This study \\
\hline $\begin{array}{l}\text { OprM-F } \\
\text { OprM-R }\end{array}$ & $\begin{array}{l}\text { ACC TAC CAG AAG AGT TTC GAC CTG } \\
\text { TGA TGT CCT TCT GGA TCT TCG CGT }\end{array}$ & 511 & $a$ & This study \\
\hline $\begin{array}{l}\text { cadA1-F } \\
\text { cadA1-R }\end{array}$ & $\begin{array}{l}\text { GCC TGC CCG TGT GCC CTG GTG A } \\
\text { CGG CGG TCT CGA TGG CGG TGT C }\end{array}$ & 823 & AF333961 & This study \\
\hline $\begin{array}{l}\text { cadA2-F } \\
\text { cadA2-F }\end{array}$ & $\begin{array}{l}\text { TTG GCG CCG AAG ACG ATA GCA CT } \\
\text { GTC GCC CAC GGT CTT CTC CAC AGG }\end{array}$ & 581 & AF333961 & This study \\
\hline $\begin{array}{l}\text { czrA-F } \\
\text { czrA-R }\end{array}$ & $\begin{array}{l}\text { CAG TGG CCG GAC CCG AAG AAG T } \\
\text { GCC CGT GGG TCC AGC GAT AGA }\end{array}$ & 1207 & Y14018 & This study \\
\hline $\begin{array}{l}\text { czrB-F } \\
\text { czrB-R }\end{array}$ & $\begin{array}{l}\text { GTG ATC AGC AGC CCG CAG TTG TC } \\
\text { TGC CCA GTT CGG ATT TGA GGA TGA }\end{array}$ & 694 & Y14018 & This study \\
\hline $\begin{array}{l}\text { czrC-F } \\
\text { czrC-R }\end{array}$ & $\begin{array}{l}\text { GGA AAC GCG CTG CTG GCT ACT G } \\
\text { TTC CGA GGT GCG CAA CTG GTC }\end{array}$ & 1020 & Y14018 & This study \\
\hline
\end{tabular}

aPCR primers for amplification of the cat and mexA-mexB region and its flanking regions were synthesized on the basis of the nucleotide sequences of the Pseudomonas genome sequencing project database (http://www.pseudomonas.com/). 
min and final extension step at $72^{\circ} \mathrm{C}$ for $5 \mathrm{~min}$. The subsequent cycling conditions are as follows for Int 1 , Int 2 and Int $3: 94^{\circ} \mathrm{C}$ for $60 \mathrm{~s}, 59^{\circ} \mathrm{C}$ for $60 \mathrm{~s}, 72^{\circ} \mathrm{C}$ for $60 \mathrm{~s}$ ( 30 cycles); aadA: $95^{\circ} \mathrm{C}$ for $60 \mathrm{~s}, 48^{\circ} \mathrm{C}$ for $30 \mathrm{~s}, 72^{\circ} \mathrm{C}$ for 60 s ( 30 cycles). PCR amplicons were analysed by electrophoresis on $1.5 \%$ agarose gels and a 100-bp ladder was used as the molecular size marker (New England Biolabs).

\section{Detection of beta lactamase resistance genes}

The PCR for the amplification of beta lactamase genes bla $_{\mathrm{TEM}}$ and bla $_{\text {SHV }}$ was carried out using primers listed in Table 1 . The reaction mixture was the same as those described for integron PCR but $1 \mu$ of 10 $\mathrm{mM}$ DNTP was used. The cycling conditions used were denaturation at $96^{\circ} \mathrm{C}$ for $5 \mathrm{~min} ; 35$ cycles of $96^{\circ} \mathrm{C}$ for $1 \mathrm{~min}, 58^{\circ} \mathrm{C}$ for $1 \mathrm{~min}$, and $72^{\circ} \mathrm{C}$ for $1 \mathrm{~min}$; and a final extension period of $72^{\circ} \mathrm{C}$ for $10 \mathrm{~min}$. Electrophoresis was performed as described for integron PCR.

\section{Detection of mexA, mex $\mathrm{B}$, and opr $\mathrm{M}$ genes}

PCR reaction mixture was as described above. PCR reactions were subjected to an initial denaturation for $5 \mathrm{~min}$, then 30 cycles with $95^{\circ} \mathrm{C}$ for $30 \mathrm{~s}$, followed by $54^{\circ} \mathrm{C}$ for $30 \mathrm{~s}$ and $72^{\circ} \mathrm{C}$ for $45 \mathrm{~s}$ with an additional elongation at $72^{\circ} \mathrm{C}$ for 5 minutes. Electrophoresis was performed as described for integron PCR.

\section{Detection of cadmium resistance genes}

PCR reaction mixture was as described above. The cycling condition used for $\mathrm{cadA}$ was an initial denaturation step at $95^{\circ} \mathrm{C}$ for $4 \mathrm{~min}$; then 35 cycles with $95^{\circ} \mathrm{C}$ for $30 \mathrm{~s}$, followed by $61.5^{\circ} \mathrm{C}(\mathrm{cadA} 1)$ or $55^{\circ} \mathrm{C}(\operatorname{cadA} 2$ and czrABC) for $30 \mathrm{~s}$ and $72^{\circ} \mathrm{C}$ for $80 \mathrm{~s}$ with an additional elongation at $72^{\circ} \mathrm{C}$ for 5 minutes. Electrophoresis was performed as described for integrin PCR.

\section{Sequencing}

The PCR products of the gene cassette and other resistance genes were purified using an Ultraclean DNA purification kit (MOBIO Laboratories, Inc.) and sequenced using the BigDye Terminator v3.1 1 cycle sequencing kit and analysed with an ABI 3100 Genetic Analyser (Flinders Medical Centre, South Australia). Primer sets used to sequence the genes are those listed in Table 1. Database similarity searches for the nucleotide sequences were carried out with BLAST at the National Centre of Biotechnology Information website (http://blast. ncbi.nlm.nih.gov/Blast.cgi).

\section{Southern hybridization}

In order to check for the co-location of cadA and aadA gene, the PCR products were digoxigenin (DIG)-labelled as probes as described by the manufacturer (Boehringer, Mannheim, Germany) and used in subsequent southern hybridisation procedures on plasmids [32].

\section{Results}

\section{Identification of isolates}

A total of 129 Pseudomonas spp. were isolated, 85 of which were from sediments and 44 from fish. The strains identified based on biochemical tests included 58 (45\%) Pseudomonas aeruginosa, 26 (20 \%) Pseudomonas fluorescens, 37 (29 \%) Pseudomonas stutzeri and eight (6\%) Pseudomonas sp. A 990 bp PCR product was obtained for isolates using the $16 \mathrm{~S}$ rRNA primers (Figure 1). There were differences in the identification obtained using 16S rRNA gene sequencing and the conventional biochemical tests [28]. With 16S rRNA methodology, 28 (22\%) Pseudomonas aeruginosa, 41 (32\%) Pseudomonas fluorescens,
9 (7\%) Pseudomonas putida, 2 (2\%) Pseudomonas syringae and 49 (38\%) Pseudomonas spp., where GenBank database similarities match Pseudomonas sp. or where there was a match with more than one Pseudomonas species.

\section{Detection of integrase, streptomycin and $\beta$-lactamase resistance genes}

Class 1 integrons were detected in 30 of the 129 (23\%) strains investigated whereas Class 2 and class 3 integrons were not detected.

$\beta$-lactamase resistance genes bla $\mathrm{TEM}_{\mathrm{TEM}}$ and $\mathrm{bla}_{\mathrm{SHV}}$ were investigated however, the genes were not detected in any of the isolates tested. Suggesting a different mechanism for the ticarcillin resistance observed.

The presence of streptomycin resistance genes was investigated in representative isolates (with $\geq 16 \mu \mathrm{g} / \mathrm{ml}$ from previous study) using primers specific for aadA gene which is normally associated with integrons and codes for resistance to streptomycin and spectinomycin; aadA gene was detected in 28 of the isolates.

\section{Detection of $\operatorname{mex} \mathrm{A}, \operatorname{mex} \mathrm{B}$, and $\operatorname{opr} \mathrm{M}$ genes}

mexB was detected in 85 of the 129 (66\%) isolates tested. Neither mexA nor oprM could be amplified with the primers used. No PCR product was obtained when the primers that amplifies the whole operon was used. Fifty-five of the Pseudomonas isolates positive for mexB, with a PCR product of 732 bp (Figure 2) were from sediments and thirty were from fish.

Some of the mexB genes obtained by PCR were sequenced to confirm the gene identity. The sequence analysis of our gene showed similarities to the Resistance-Nodulation-Division family (RND) multidrug efflux transporters including mex $\mathrm{B}$ and its different homolog $\operatorname{TtgB}$, so called because in addition to multidrug efflux it is also able to transport toluene; which have been described in Pseudomonas spp.

The sequences obtained have been deposited in the Genbank under the nucleotide sequence accession numbers listed in Table 2.

\section{Detection of cadmium resistance genes}

The Pseudomonas strains with cadmium Minimum Inhibitory Concentration (MIC) of $\geq 200 \mu \mathrm{g} / \mathrm{ml}$ were investigated for the presence of cadmium resistance gene. The cadA gene which was a PCR product

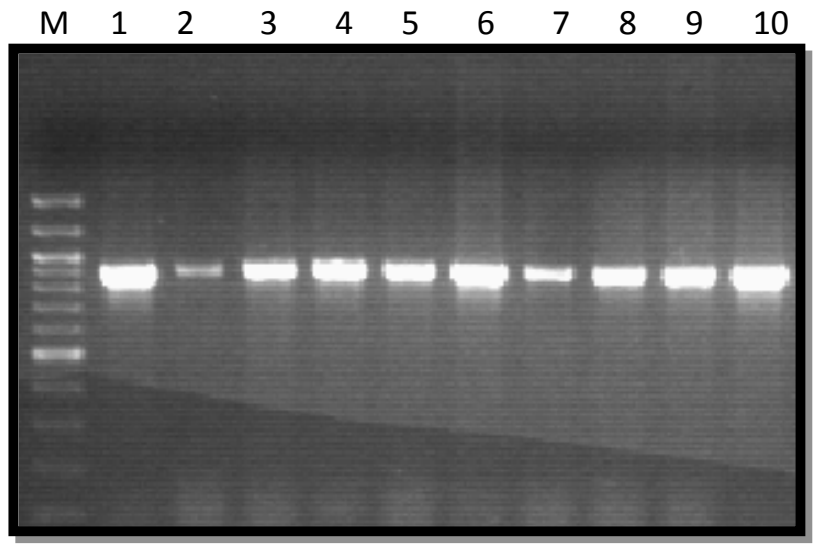

Figure 1: Example of an ethidium bromide stained gel of PCR products for the 16S rRNA identification of Pseudomonas spp.

M: 100 bp marker. Lane 1-10 shows different Pseudomonas isolates positive for the $990 \mathrm{bp} \mathrm{PCR}$ product of the universal 16S rRNA primers. 
of $823 \mathrm{bp}$ (Figure 3) was detected in 59 of the $92(64 \%)$ isolates tested. The homolog of the czc genes, called czr, was not detected in any of the isolates. Thirty-five of the Pseudomonas strains carrying cadA were from sediments and twenty-four were from fish.

Plasmid DNA was extracted from 129 Pseudomonas isolates and 55 of them were found to possess plasmids. It was found that 29 of the 59 (49\%) cadA positive isolates possessed plasmids.

The southern hybridization of plasmids with the cadA as probe did not reveal the presence of $c a d \mathrm{~A}$ on the plasmid, suggesting that $c a d \mathrm{~A}$ is likely to be chromosomally located. Some of the cadA genes obtained were sequenced to confirm the gene identity. The sequence analysis confirms similarities to the cadmium translocating P-type ATPases, cadA of various Pseudomonas spp. The sequences obtained have been deposited in the Genbank under the nucleotide sequence accession numbers and are listed in Table 2.

\section{Discussion}

The association of integrons with various resistance gene cassettes in aquatic environments has been well documented [33-37], however there are few reports of integron and associated resistance genes in Pseudomonas spp. There is limited information on the occurrence of integrons and other resistance genes in bacteria of aquaculture origin

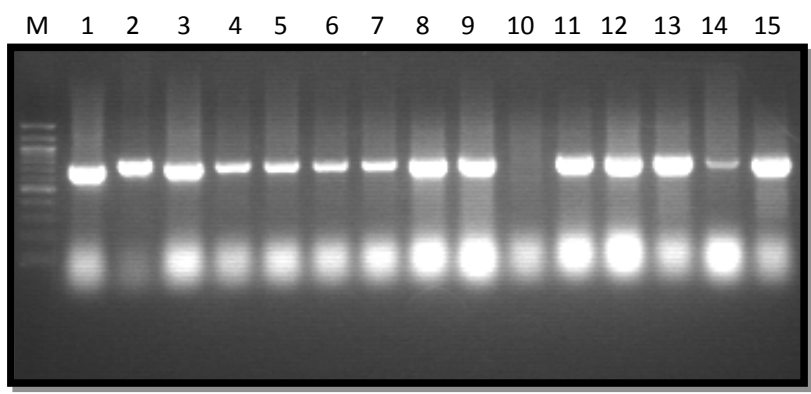

Figure 2: An example of ethidium bromide stained gel showing the 732 bp PCR product obtained for mexB in different Pseudomonas isolates obtained from sediment samples.

M: 100 bp marker; Lane: 1, 2, 6, 8-11, 13 ( $P$. aeruginosa; lane 10 is negative for mexB); Lane: 3, 12, 15 (P. fluorescens); Lane: 4, 5, 714 (P. stutzeri).

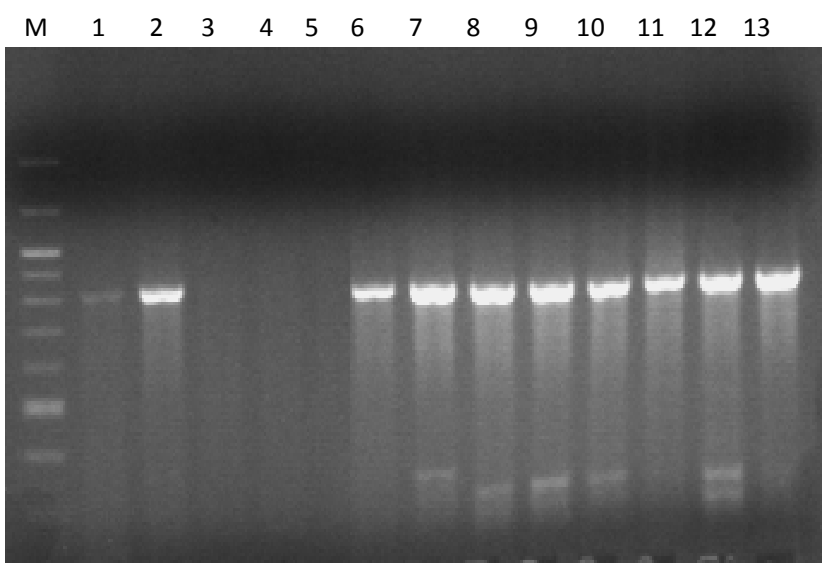

Figure 3: An example of ethidium bromide stained gel showing the $823 \mathrm{bp}$ PCR product obtained for cadA in different Pseudomonas isolates obtained from fish samples.

$\mathrm{M} ; 100$ bp marker; lane: 1, 2, 6-13 shows strains that were positive for cadA and lane 3-5 shows strains that were negative for cadA. in Australia $[38,39]$. Integrons are known to have the capacity to carry many antibiotic resistance genes and so the resistant Pseudomonas strains were investigated for the presence or absence of integrase genes for class 1, class 2 and class 3 integrons. In this study, Class 1 integron was detected in 30 of the 129 strains investigated. Streptomycin resistance gene aadA was detected in 28 of the 59 integrase positive strains; the primers used were specific for the detection of the aadAla gene cassette and other closely related aadA gene cassettes (with the exception of aadA4 and aadA5). The presence of aadA and other resistance gene cassettes in different aquatic environments has been reported [33,35,37]; it is therefore not surprising to detect these genes in the isolates tested.

It is a well known fact that the members of the family Pseudomonadaceae show significant intrinsic resistance to a wide variety of structurally unrelated compounds [40,41]. The intrinsic resistance previously attributed only to non-specific impermeability of the outer membrane [42] is now known to result from a synergy with drug efflux pumps with a wide spectrum of activity [43].

One of the efflux system, mexAB-oprM that was investigated in this study encodes a tripartite pump is able to exports a wide range of antibiotics including chloramphenicol and $\beta$-lactams $[21,44,45]$. The detection of mex $\mathrm{B}$, the major integral inner membrane efflux component of the mex $\mathrm{AB}$-oprM pump in a large number of our isolates clearly suggests that some of the natural/intrinsic resistance of these isolates is partly as a result of this efflux system. A similar mechanism has been described in clinical $P$. aeruginosa strains which were meropenem resistant; where mexB was detected in all blaIMP, $b l a_{\mathrm{SPM}}$ and $b l a_{\mathrm{VIM}}$ negative isolates [46]. The sequence analysis of isolates from this study demonstrated similarity to the RND multidrug efflux transporter mexB and its homologue TtgB which in addition to multidrug efflux also transports toluene out of the cell and have been described in P. putida [47,48], and in P. fluorescens Pf-5 genome sequence. No PCR product was obtained when the primers that amplifies the whole operon mexAB-oprM was used, this could be that it was too large to amplify.

$\beta$-lactamase resistance genes $b l a_{\mathrm{TEM}}$ and $b l a_{\mathrm{SHV}}$ were investigated however, the genes were not detected in any of the isolates tested suggesting a different mechanism for the ticarcillin resistance observed.

In addition to some antibiotic resistance mechanisms, we also report the incidence of the heavy metal resistance determinant, cadA gene in 59 of the 92 strains tested. A well characterised cadmium resistance system in Gram-negative bacteria is the cadmium, zinc and cobalt $(c z c)$ resistance determinant of Alcaligenes eutrophus where the $c z c \mathrm{C}$, $c z c \mathrm{~B}$, and $c z c \mathrm{~A}$ proteins comprise an active efflux mechanism driven by antiporter, rather than a cation transporting ATPase [49]. A homolog of the $c z c$ gene, called $c z r$, which confers cadmium and zinc resistance, have been identified in the chromosome of $P$. aeruginosa and appear to be highly conserved in environmental isolates of that species [27]; however this resistance determinant was not detected in our isolates. Instead we detected cadA which is mostly found in Gram-positive bacteria [50-53]. The genome sequences of several Gram-negative bacteria have revealed homologs of cadA $[54,55]$ and there are some reports of cadA-encoded cadmium resistance being identified in some Pseudomonas species [56,57]. The cadA gene detected in this study is believed to be chromosomally located since southern hybridisation did not detect the presence of the gene on the plasmids in any of the isolates tested. Chromosomally located cadA have also been reported in P. putida [57].

There are reports of correlation between heavy metal contamination 
Citation: Ndi OL, Barton MD (2012) Resistance Determinants of Pseudomonas Species from Aquaculture in Australia. J Aquac Res Development 3:119 doi:10.4172/2155-9546.1000119

Page 5 of 6

\begin{tabular}{|l|l|l|l|l|}
\hline ACCESSION NUMBER & GENE & CODE & ORGANISM \\
\hline EF636685 & mexB & SNFP3 & P. aeruginosa \\
\hline EF636686 & mexB & SNSP18 & P. fluorescens \\
\hline EF636687 & mexB & SNSP28 & P. fluorescens \\
\hline EF636689 & mexB & SNSP22 & P. stutzeri \\
\hline EF636688 & mexB & SNFP21 & P. stutzeri \\
\hline EF636682 & cadA & SNSP5 & P. aeruginosa \\
\hline EF636683 & cadA & SNFP24 & P. stutzeri \\
\hline
\end{tabular}

Table 2: Nucleotide sequence accession numbers.

and antimicrobial resistance [58,59] and this is a potential public health concern. Pseudomonas spp. carrying integrons, efflux gene and cadmium resistance genes are present in farm-raised fish and sediments even though no antibiotics were licensed for use in Australian aquaculture at the time of the study.

\section{Conclusion}

Int 1 of Class one integrons and aadA genes were detected in addition to mex $\mathrm{B}$, the major integral inner membrane efflux component of the mexAB-oprM pump which would account for some of the intrinsic resistance. However, this pump can also mediate resistance to many antibiotics. Cadmium resistance gene cadA was also detected in the isolates. These results suggest that bacteria from farmed raised fish and environments in Australia are potential sources of antibiotic and heavy metal resistance genes in the environment. Established environmental reservoirs of resistance genes can lead to contamination of food and human water sources and this has great implications for public health.

\section{Acknowledgement}

We thank Dr Peter Grant of the Department of Primary Industries, Victoria for helping with the sample collection for this study, Professor Hatch Stokes of Macquarie University, Sydney, for helpful advice on integrons and Professor Julian Rood of Monash University for the E. coli strain.

\section{References}

1. Jensins LJ, Skovgaard $M$, Sicheritz-Ponten $T$, Hansen NT, Johansson $\mathrm{H}$, et al. (2004) Comparative genomics of four Pseudomonas species. in Pseudomonas:Genomics, Lifestyle and Molecular architecture, Ramos J-L, Editor, Juan-Luis Ramos Kluwer Academic Plenum: New- York.

2. Yamagishi Y, Fujita J, Takigawa K, Negayama K, Nakazawa T, et al. (1997) Clinical features of Pseudomonas cepacia pneumonia in an epidemic among immunocompromised patients. Chest 103: 1706-1709.

3. Lang AB, Horn MP, Imboden MA, Zuercher AW (2004) Prophylaxis and therapy of Pseudomonas aeruginosa infection in cystic fibrosis and immunocompromised patients. Vaccine 22: S44-48.

4. Shiose J, Wakabayashi H, Tominaga M, Egusa S (1974) A report on a disease of cultured carp due to a capdulated Pseudomonas. Fish Pathol 9: 79-83.

5. Alderman DJ, Polglase JL (1988) Pathogens, parasites and commensals. In: in Freshwater crayfish-Biology, management and exploitation, Holdich DM and Lowry RS, Editors, Timber Press: Portland, Oregon.

6. Wakabayashi H, Egusa S (1972) Characteristics of a Pseudomonas sp. from an epizootic of pond cultured eels (Anguilla japonica). Bull Japan Soc Sci Fisheries 38: 577-587.

7. Hatai K, Egusa S, Nakajima M, Chikahata H (1975) Pseudomonas chlororaphis as a fish pathogen. Bull Japan Soc Sci Fisheries 41: 1203

8. Kobayashi T, Imai M, Ishitaka Y, Kawaguchi Y (2000) Histopathological studies of bacterial haemorrhagic ascites of ayu, Plecoglossus altivelis (Temminck and schlegel). J Fish Dis 27: 451-457.

9. Altinok I, Kayis S, Capkin E (2006) Pseudomonas putida infection in rainbow trout. Aquaculture 261: 850-855.

10. Aviles M, Codina JC, Perez-Garcia A, Cazorla f, Romero P, et al. (1993) Occurence of resistance to antibiotics and metals and of plasmids in bacteria strains isolated from marine environments. Water Sci Technol 27: 475-478.
11. Russsel AD, Day MJ (1996) Antibiotic and biocide resistance in bacteria Microbios 85: 45-65.

12. Maniati M, Ikonomidis A, Mantzana P, Maniatis A, Pournaras S (2007) Pseudomonas aeruginosa with a novel blaVIM-4/blaP1b and a second class-1 integron, effiux pumps overexpression and repressed porin OprD. Int $J$ Antimicrob Agents 29: S106.

13. Holmes AJ, Holley MP, Mahon A, Nield B, Gillings M, et al. (2003) Recombination Activity of a Distinctive Integron-Gene Cassette System Associated with Pseudomonas stutzeri Populations in Soil. J Bacteriol 185 918-928.

14. Unaldi MN, Korkmaz H, Arıkan B, Coral G (2003) Plasmid-Encoded Heavy Metal Resistance in Pseudomonas sp. Bull Environ Contam Toxicol 71: 11451150.

15. Aires JR, Kohler T, Nikaido $H$, Plesiat $P$ (1999) Involvement of an active efflux system in the natural resistance of Pseudomonas aeruginosa to aminoglycosides. Antimicrob Agents Chemother 43: 2624-2628.

16. Wolter DJ, Smith-Molland E, Goering RV, Hanson ND, Lister PD (2004) Multidrug resistance associated with mexXY expression in clinical isolates of Pseudomonas aeruginosa from a Texas hospital. Diagn Microbiol Infect Dis 50: $43-50$.

17. Poole K, Gotoh N, Tsujimoto H, Zhao Q, Wada A et al (1996) Overexpression of the mexC-mexD-OprJ efflux operon in $n f x B$ multidrug resistant strains of Pseudomonas aeruginosa. Mol Microbiol 21: 713-724.

18. Masuda N, Sakagawa E, Ohya S, Gotoh N, Tsujimoto H, et al. (2000) Contribution of the MexX-MexY-OprM efflux system to intrinsic resistance in Pseudomonas aerugionsa. Antimicrob Agents Chemother 44: 2242-2246.

19. Alvarez AH, Moreno-Sa'nchez R, Cervantes C (1999) Chromate Efflux by Means of the ChrA Chromate Resistance Protein from Pseudomonas aeruginosa. J Bacteriol 181: 7398-7400.

20. Baker-Austin, Wright MS, Stepanauskas R, McArthur JV (2006) Co-selection of antibiotic and metal resistance. Trends Microbiol 14: 176-182.

21. Li X-Z, Livermore DM, Nikaido H (1994) Role of efflux pump(s) in intrinsic resistance of Pseudomonas aeruginosa: Resistance to tetracycline chloramphenicol and norfloxacin. Antimicrob Agents and Chemother 38: 1732 1741.

22. Zgurskaya HI, Nikaido H (2000) Multidrug resistance mechanisms:drug efflux across two membranes. Mol Microbiol 37: 219-225.

23. Stover CK, Pham XQ, Erwin AL, Mizoguchi SD, Warrener $P$, et al. (2000) Complete genome sequence of Pseudomonas aeruginosa PA01, an opportunistic pathogen. Nature 406: 959-964.

24. Li XZ, Nikaido H (2004) Efflux-mediated drug resistance in bacteria. Drugs 64 159-204.

25. Trevor JT, Stratton GW, Gadd GM (1986) Cadmium transport, resistance, and toxicity in bacteria, algae, and fungi. Can J Microbiol 32: 447-464

26. Silver S, Walderhaug M (1992) Gene regulation and chromosome determined inorganic ion transport in bacteria. Microbiol Mol Biol Rev 56: 195-228.

27. Hassan M-e-T, van der Lelie D, Springael D, Römling U, Ahmed N, et al. (1999) Identification of a gene cluster, czr, involved in cadmium and zinc resistance in Pseudomonas aeruginosa. Gene 238: 417-425.

28. Akinbowale OL, Peng H, Grant P, Barton M (2007b) Antibiotic and heavy metal resistance in motile aeromonads and pseudomonads from rainbow trout (Oncorhynchus mykiss) farms in Australia. Int J Antimicrob Agents 30: 177-182.

29. Dillon B, Thomas L, Mohmand G, Zelynski A, Iredell J (2005) Multiplex PCR 
Citation: Ndi OL, Barton MD (2012) Resistance Determinants of Pseudomonas Species from Aquaculture in Australia. J Aquac Res Development 3:119 doi:10.4172/2155-9546.1000119

for screening of integrons in bacterial lysates. J Microbiol Methods 62: 221 232

30. Koelman JGM, Stoof J, Van Der Bijl MW, Vandenbroucke-Grauls CMJE, Savelkoul PHM (2001) Identification of epidemic strains of Acinetobacter baumannii by integrase gene PCR. J Clinical Microbiol 39: 8-13.

31. Mazel D, Dychinco B, Webb VA, Davies J (2000) Antibiotic resistance in the ECOR collection: integrons and identification of a novel aad gene. Antimicrob Agents Chemother 44: 1568-1574.

32. Sambrook J, Fritsch EF, Maniatis T (1989) Molecular Cloning: A Laboratory Manual Cold Spring Harbor Laboratory Press: Cold Spring Harbor, New York.

33. Jacobs L, Chenia HY (2007) Characterization of integrons and tetracycline resistance determinants in Aeromonas spp. isolated from South African aquaculture systems. Int J Food Microbiol 114: 295-306.

34. Petersen A, Guardabassi L, Dalsgaard A, Olsen JE (2000) Class I integrons containing a dhfr1 trimethoprim resistance gene cassette in aquatic Acinetobacter spp. FEMS Microbiol Lett 182: 73-76.

35. L'Abee-Lund TM, Sorum H (2001) Class I integrons mediated antibiotic resistance in the fish pathogen Aeromonas salmonicida world-wide. Microb Drug Resist 7: 263-272.

36. Agerso Y, Guardabassi L (2005) Identification of Tet 39, a novel class of tetracycline resistance determinant in Acinetobacter spp. of environmental and clinical origin. J Antimicrob Chemother 55: 566-569.

37. Schmidt AS, Bruun MS, Dalsgaard I, Larsen JL (2001) Incidence, distribution and spread of tetracycline resistance determinants and integron-associated antibiotic resistance genes among motile aeromonads from fish farming environment. Appl Environ Microbiol 67: 5675-5682.

38. Akinbowale OL, Peng H, Barton M (2007a) Diversity of tetracycline resistance genes in bacteria from aquaculture sources in Australia. J Appl Microbiol 103 2016-2025.

39. Ndi OL, Barton MD (2011) Incidence of class 1 integron and other antibiotic resistance determinants in Aeromonas spp. from rainbow trout farms in Australia. J Fish Dis 34: 589-599.

40. Nikaido $H$ (1996) Multidrug efflux pumps of gram-negative bacteria. J Bacterio 178: $5853-5859$

41. Paulsen IT, Brown MH, Skurray RA (1996) Proton-dependent multidrug efflux systems. Microbiol Rev 60: 575-608.

42. Nikaido H (1994) Prevention of drug access to bacterial targets: permeability barriers and active efflux. Science 264: 382-388.

43. Ma D, Cook DN, Hearst JE, Nikaido H (1994) Efflux pumps and drug resistance in Gram-negative bacteria. Trends Microbiol 2: 489-493.

44. Gotoh N, Tsujimoto H, Poole K, Yamagishi JI, Nishino T (1995) The outer membrane protein OprM of Pseudomonas aeruginosa is encoded by OprK of the MexA-MexB-OprK multidrug resistance operon. Antimicrob Agents Chemother 39: 2567-2569.

45. Poole K, Krebes K, McNally C, Neshat S (1993) Multiple antibiotic resistance in Pseudomonas aeruginosa: evidence for involvement of an efflux operon. J Bacteriol 175: 7363-7372.

46. Pournaras S, Maniati M, Spanakis N, Ikonomidis A, Tassios PT, et al. (2005) Spread of efflux pump-overexpressing, non-metallo- $\beta$-lactamase-producing, meropenem-resistant but ceftazidime-susceptible Pseudomonas aeruginosa in a region with blaVIM endemicity. J Antimicrob Chemother 56: 761-764.

47. Ramos JL, Duque E, Godoy P, Segura A (1998) Efflux pumps involved in toluene tolerance in Pseudomonas putida DOT-T1E. J Bacteriol 180: 33233329.

48. Rojas A, Duque E, Mosqueda G, Golden G, Hurtado A, et al. (2001) Three Efflux Pumps Are Required To Provide Efficient Tolerance to Toluene in Pseudomonas putida DOT-T1E. J Bacteriol 183: 3967-3973.

49. Nies DH, Nies A, Chu L, Silver S (1989) Expression and nucleotide sequence of a plasmid-determined divalent cation efflux system from Alcaligenes eutrophus. Proc Natl Acad Sci USA 86: 7351-7355.

50. Silver S, Phung LT (1996) Bacterial heavy metal resistance: New Surprises. Annu Rev Microbiol 50: 753-789.

51. Nucifora G, Chu L, Misra TK, Silver S (1989) Cadmium resistance from
Staphylococcus aureus plasmid pl258 cadA gene results from cadmium-efflux ATPase. Proc Natl Acad Sci USA 86: 3544-3548.

52. Lebrun M, Audurier A, Cossart P (1994) Plasmid-borne cadmium resistance genes in Listeria monocytogenes are present on Tn5422, a novel transposon closely related to Tn917. J Bacteriol 176: 3049-3061.

53. Oger C, Mahillon J, Petit F (2003) Distribution and diversity of a cadmium resistance (cadA) determinant and occurrence of IS257 insertion sequences in Staphylococcal bacteria isolated from a contaminated estuary (Seine, France). FEMS Microbiol Ecol 43: 173-183.

54. Herrmann L, Schwan D, Garner R, Mobley HL, Haas R, et al. (1999) Helicobacter pylori cadA encodes an essential Cd(II)- Zn(II)-Co(II) resistance factor influencing urease activity. Mol Microbiol 33: 524-536.

55. Rensing C, Mitra B, Rosen BP (1997) The zntA gene of Escherichia coll encodes a Zn(II)-translocating P-type ATPase. Proc Natl Acad Sci USA 94 14 326-14 331

56. Yoon KP (1998) Isolation and characterization of Pseudomonas sp. KM10, a cadmium- and mercury-resistant, and phenol-degrading bacterium. J Microbiol Biotechnol 8: 388-398.

57. Lee E-W, Glickmann E, Cooksey DA (2001) Chromosomal Locus for Cadmium Resistance in Pseudomonas putida Consisting of a Cadmium-Transporting ATPase and a MerR Family Response Regulator. Appl Environ Microbiol 67: 1437-1444.

58. Knapp CW, McCluskey SnM, Singh BK, Campbell CD, Hudson G, et al (2011) Antibiotic Resistance Gene Abundances Correlate with Metal and Geochemical Conditions in Archived Scottish Soils. PLoS ONE 6: e27300.

59. Nostrand J, Khijniak T, Gentry T, Novak M, Sowder A, et al. (2007) Isolation and characterization of four Gram-positive nickel-tolerant microorganisms from contaminated sediments. Microb Ecol 53: 670-682.

60. Widmer F, Seidler R, Gillevet P, Watrud LS, Giovanni GD (1998) A Highly Selective PCR Protocol for Detecting 16S rRNA Genesof the Genus Pseudomonas (Sensu Stricto) in Environmental Samples. Appl Environ Microbiol 64: 2545-2553.

61. Rasheed JK, Jay C, Metchock B, Berkowitz F, Weigel L, et al. (1997) Evolution of extended-spectrum beta-lactam resistance (SHV-8) in a strain of Escherichia coli during multiple episodes of bacteremia. Antimicrob Agents Chemother 41: 647-653.

62. Masuda N, Sakagawa E, Ohya S, Gotoh N, Tsujimoto H, et al. (2000) Contribution of the MexX-MexY-OprM efflux system to intrinsic resistance in Pseudomonas aerugionsa. Antimicrob Agents Chemother 44: 2242-2246. 